\title{
Synthesis, Characterization and Catalytic Activity of Two Novel cis-Dioxovanadium(V) Complexes: $\left[\mathrm{VO}_{2}(\mathrm{~L})\right]$ and $\left[\mathrm{VO}_{2}(\mathrm{HLox})\right]$
}

\author{
Natália M. L. Silva, ${ }^{a}$ Carlos B. Pinheiro, ${ }^{b}$ Eluzir P. Chacon, ${ }^{a}$ Jackson A. L. C. Resende, ${ }^{a}$ \\ José Walkimar de M. Carneiro, ${ }^{a}$ Tatiana L. Fernández, ${ }^{c}$ Marciela Scarpellini ${ }^{c}$ and \\ Mauricio Lanznaster $*$,a \\ ${ }^{a}$ Instituto de Química, Universidade Federal Fluminense, Outeiro S. João Batista S/N, \\ 24020-141 Niterói-RJ, Brazil \\ ${ }^{b}$ Departamento de Física, Universidade Federal de Minas Gerais, Av. Antonio Carlos 6627, \\ Pampulha, 31270-901 Belo Horizonte-MG, Brazil \\ 'Instituto de Química, Universidade Federal do Rio de Janeiro, Av. Athos da Silveira Ramos 149, \\ Bl. A, 21941-909 Rio de Janeiro-RJ, Brazil
}

\begin{abstract}
Dois novos complexos $\left[\mathrm{VO}_{2}(\mathrm{~L})\right]$ e $\left[\mathrm{VO}_{2}(\mathrm{HLox})\right]$ foram sintetizados e caracterizados por espectroscopias no IV, UV-Vis e RMN, voltametria cíclica, análise elementar e difração de raios X. A síntese do ligante inédito $\mathrm{H}_{2}$ Lox também é descrita. Os complexos $\mathbf{1}$ e $\mathbf{2}$ foram obtidos pela reação de $\left[\mathrm{VO}(\mathrm{acac})_{2}\right]$ com os respectivos ligantes $\mathrm{HL}$ e $\mathrm{H}_{2}$ Lox. Alternativamente, 2 foi preparado a partir da reação de $\mathrm{HL}$ com $\left[\mathrm{VO}(\mathrm{acac})_{2}\right]$ na presença de hidroxilamina, e através da reação de 1 com hidroxilamina. Dados cristalográficos mostram que 1 e 2 apresentam estruturas moleculares similares, onde o centro de vanádio(V) cis-dioxo encontra-se coordenado em um ambiente octaédrico distorcido formado pelos ligantes $\mathrm{L}^{-}$e $\mathrm{HLox}^{-}$, respectivamente. A atividade catalítica destes compostos foi avaliada na oxidação do cicloexano, utilizando $\mathrm{H}_{2} \mathrm{O}_{2}$ e $t$-BuOOH como oxidantes. Ambos apresentam seletividade $>70 \%$ para formação de cicloexilidroperóxido. Cálculos B3LYP/6-31G(d) foram empregados na otimização da geometria e para auxiliar na atribuição do espectro eletrônico.
\end{abstract}

Two novel complexes, $\left[\mathrm{VO}_{2}(\mathrm{~L})\right](\mathbf{1})$ and $\left[\mathrm{VO}_{2}(\mathrm{HLox})\right](\mathbf{2})$, were synthesized and characterized by IV, UV-Vis and NMR spectroscopy, cyclic voltammetry, elemental analysis and X-ray diffraction. The synthesis of a new ligand, $\mathrm{H}_{2}$ Lox, is also described. Complexes $\mathbf{1}$ and $\mathbf{2}$ were obtained by the reaction of $\left[\mathrm{VO}(\mathrm{acac})_{2}\right]$ with the ligands $\mathrm{HL}$ and $\mathrm{H}_{2} \mathrm{Lox}$, respectively. Alternatively, 2 was also obtained by the reaction of $\mathrm{HL}$ with $\left[\mathrm{VO}(\mathrm{acac})_{2}\right]$ in the presence of hydroxylamine, and by the reaction of $\mathbf{1}$ with hydroxylamine. Crystallographic data show that complexes $\mathbf{1}$ and $\mathbf{2}$ have similar molecular structures, in which the cis-dioxovanadium(V) center is coordinated to $\mathrm{L}^{-}$or $\mathrm{HLox}^{-}$, respectively, in a distorted octahedral environment. The catalytic activity of these compounds towards cyclohexane oxidation was evaluated using $\mathrm{H}_{2} \mathrm{O}_{2}$ and $t$ - $\mathrm{BuOOH}$ as oxidants. Both complexes presented $>70 \%$ selectivity for cyclohexylhydroperoxide formation. B3LYP/6-31G(d) calculations were used to confirm the geometry and to help assign the electronic spectra.

Keywords: oxovanadium(V), bioinspired catalysts, peroxide activation

\section{Introduction}

Vanadium coordination chemistry has received attention in recent years due to its presence in several biological systems and its applications in catalysis. The first example of vanadium-dependent enzyme are the vanadium

\footnotetext{
*e-mail: mlanz@vm.uff.br
}

haloperoxidases (VHPOs), isolated from the marine algae Ascophyllum nodosum. ${ }^{1,2}$ Later, these enzymes were isolated from different sources such as seaweed, lichens and other algae and characterized as iodoperoxidases, bromoperoxidases and chloroperoxidases, depending on the most electronegative halogen the enzyme is capable of oxidizing. ${ }^{3}$ These enzymes are responsible for the two-electron oxidation catalyses of chloride, bromide 
and iodide by hydrogen peroxide and are involved in the halogenation of a large variety of organic substrates in vivo. ${ }^{4}$ The discovery of its structure initiated the investigation of vanadium complexes as functional and structural models for these enzymes. ${ }^{5}$ Special attention was given by Pecoraro and co-workers ${ }^{6}$ who proposed the catalytic cycle for the vanadium haloperoxidases based on the behavior of several compounds.

As oxovanadium(IV) and (V) complexes are strong Lewis acids, due to their high charge to radius ratio, they can activate peroxide reagents and then be used as catalysts in several oxidation reactions of organic compounds, such as oxidation of sulfides to sulfoxides and sulfones, alkene epoxidation and hydroxylation, aromatic, alkane and alcohol oxidations, and inorganic compounds such as halide and $\mathrm{SO}_{2}$ oxidation. ${ }^{7-13}$

Among the hydrocarbon oxidation reactions, catalytic oxidation of alkanes is especially interesting because this kind of reaction leads to products which have considerable application in the pharmaceutical and plastic industry. The cyclohexane oxidation into cyclohexanol and cyclohexanone is a very important industrial reaction for the manufacture of Nylon-6 and Nylon-6,6, which is achieved with high temperature and pressure. ${ }^{14,15}$ To obtain these oxidized products, the actual industrial process requires temperature and pressure over $150^{\circ} \mathrm{C}$ and $115 \mathrm{psi}$, respectively; and only about $3-8 \%$ of overall conversion is attained. ${ }^{16}$ Thus, the development of bioinspired catalysts, which have low activation energy and require friendly oxidants, embrace important advantages from the environmental standpoint. ${ }^{16-18}$ In this way, a number of model complexes for vanadium containing enzymes and other vanadium complexes had their catalytic properties evaluated towards the peroxidative oxidation of alkenes and aromatic hydrocarbons. ${ }^{6,19-23}$

In this work, we present the synthesis and characterization of two novel vanadium(V) cis-dioxo complexes of general formula $\left[\mathrm{VO}_{2}(\mathrm{~L})\right]$ and $\left[\mathrm{VO}_{2}(\mathrm{HLox})\right]$, where $\mathrm{HL}=$ (3-[(bis-pyridin-2-yl-methylamino)-methyl]-2-hydroxy-5methyl-benzaldehyde $)$ and $\mathrm{H}_{2}$ Lox $=$ (3-[(bis-pyridin-2-ylmethylamino)-methyl]-2-hydroxy-5-methyl-benzaldehyde oxime), and preliminary reactivity studies on the catalytic oxidation of cyclohexane by these complexes employing $\mathrm{H}_{2} \mathrm{O}_{2}$ or $t$-BuOOH as oxidants.

\section{Experimental}

\section{Materials and methods}

Reagents and solvents were used without further purification. High purity (99\%) cyclohexane, cyclohexanol and cyclohexanone were purchased from Merck and used as received from freshly opened bottle. In addition, their purity was checked out by gas chromatography (GC). The oxidation agents $\mathrm{H}_{2} \mathrm{O}_{2}(30 \%)$ and $t$ - $\mathrm{BuOOH}(70 \%)$ were, respectively, purchased from Vetec and Across, and their real concentrations were determined by iodometric titrations $\left(\left[\mathrm{H}_{2} \mathrm{O}_{2}\right]=11.8 \mathrm{~mol} \mathrm{~L}^{-1}\right.$ and $\left.[t-\mathrm{BuOOH}]=7.5 \mathrm{~mol} \mathrm{~L}^{-1}\right)$. Microanalysis were performed using a Perkin-Elmer CHN 2400 micro analyzer at the Central Analítica do Instituto de Química, Universidade de São Paulo, SP, Brazil. UV-Visible absorption spectra were recorded from $1.0 \times 10^{-4} \mathrm{~mol} \mathrm{~L}^{-1}$ dimethyl sulfoxide (HPLC grade, Tedia) solutions on a Varian Cary 50 spectrophotometer, using $1 \mathrm{~cm}$ optical length quartz cuvettes. IR spectra (KBr pellets) were recorded on a FT-IR Spectrum One (Perkin Elmer) spectrophotometer. ${ }^{1} \mathrm{H}$ NMR spectra were recorded on a Varian Unit Plus $300 \mathrm{MHz}$ spectrometer in DMSO- $d_{6}$; chemical shifts $(\delta)$ are reported in parts per million (ppm) relative to the internal standard $\mathrm{Me}_{4} \mathrm{Si}$. The hydrogen signals were attributed based on the coupling constant values $(J)$ and 2D COSY experiments. Cyclic voltammetry experiments were carried out in a BAS Epsilon potentiostat-galvanostat system, using a conventional electrochemical cell with three electrodes: $\mathrm{Ag} / \mathrm{AgCl}$ for organic media as reference, platinum wire as auxiliary, and glassy carbon as working electrode. Electrochemical grade tetrabutylammonium hexafluorophosphate $\left(\mathrm{TBAPF}_{6}\right.$, Sigma Aldrich) $0.1 \mathrm{~mol} \mathrm{~L}^{-1}$ in DMSO (Tedia Anhydrosolv) was used as supporting electrolyte, and the whole cell was deoxygenated using ultrapure argon. Ferrocene was used as an internal reference $\left(\mathrm{E}_{1 / 2}=0.40 \mathrm{~V} v s\right.$. NHE). ${ }^{24}$

\section{Syntheses of HL and HLox}

The synthesis of HL was previously reported. ${ }^{25}$ The ligand HLox was prepared according to Scheme 1. An ethanol solution of HL (1.25 g, $3.60 \mathrm{mmol})$, hydroxylamine hydrochloride $(0.50 \mathrm{~g}, 3.60 \mathrm{mmol})$ and sodium carbonate ( $0.38 \mathrm{~g}, 3.60 \mathrm{mmol})$ was stirred under reflux during $24 \mathrm{~h}$. The solvent was removed under vacuum, and the resulting oil was dissolved in dichloromethane and washed with water. The organic layer was dried over $\mathrm{MgSO}_{4}$ and the solvent was removed under vacuum. The product was obtained as a greenish viscous oil $(1.04 \mathrm{~g}, 80 \%) ;{ }^{1} \mathrm{H}$ NMR (300 $\mathrm{MHz}, \mathrm{CDCl}_{3}, 25^{\circ} \mathrm{C}$ ), $\delta 8.53$ (ddd, J 4.98, 1.68, $\left.0.80 \mathrm{~Hz}, 2 \mathrm{H}, \mathrm{H}^{\mathrm{a}}\right), 8.40\left(\mathrm{~s}, 1 \mathrm{H}, \mathrm{H}^{\mathrm{g}}\right), 7.65(\mathrm{td}, J$ 7.69, 7.69, $\left.1.78 \mathrm{~Hz}, 2 \mathrm{H}, \mathrm{H}^{\mathrm{c}}\right), 7.49$ (d, J $7.84 \mathrm{~Hz}, 2 \mathrm{H}, \mathrm{H}^{\mathrm{d}}$ ), 7.16 (ddd, $J$ 7.47, 4.99, $\left.1.10 \mathrm{~Hz}, 2 \mathrm{H}, \mathrm{H}^{\mathrm{b}}\right), 7.12\left(\mathrm{~d}, J 1.74 \mathrm{~Hz}, 2 \mathrm{H}, \mathrm{H}^{\mathrm{e}}\right.$ and $\mathrm{H}^{\mathrm{f}}$ ), 3.99 (s, $4 \mathrm{H}, \mathrm{N}-\mathrm{CH}_{2}-\mathrm{py}$ ), 3.88 (s, 2 H, N-CH $-\mathrm{Ar}$ ), $2.24\left(\mathrm{~s}, 3 \mathrm{H}, \mathrm{CH}_{3}\right) ; \mathrm{IR} v_{\max } / \mathrm{cm}^{-1}(\mathrm{KBr}) 1596,1473,1440$ $v(\mathrm{C}=\mathrm{C}, \mathrm{C}=\mathrm{N}), 1231 \mathrm{v}(\mathrm{C}-\mathrm{O}), 763 \delta(\mathrm{C}-\mathrm{H})$. 


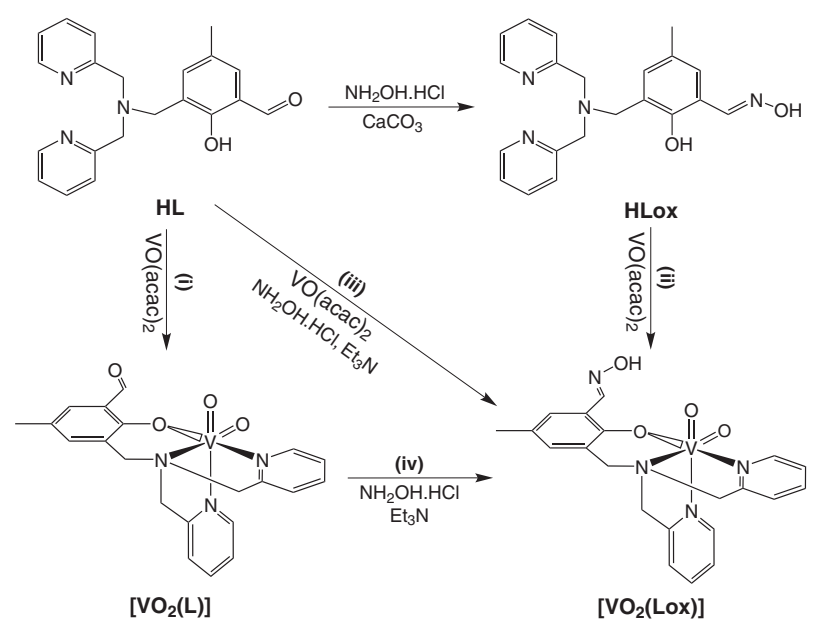

Scheme 1. Synthesis of HL, HLox, $\left[\mathrm{VO}_{2}(\mathrm{~L})\right](\mathbf{1})$ and $\left[\mathrm{VO}_{2}(\mathrm{Lox})\right](2)$.

Synthesis of $\left[\mathrm{VO}_{2}(L)\right](\mathbf{1})$

(i). To a solution of HL ( $174 \mathrm{mg}, 0.5 \mathrm{mmol}$ ) in methanol $(30 \mathrm{~mL})$ was added $\left[\mathrm{VO}(\mathrm{acac})_{2}\right](132 \mathrm{mg}, 0.5 \mathrm{mmol})$ and the mixture heated at $80^{\circ} \mathrm{C}$ under stirring for $30 \mathrm{~min}$. After cooling to room temperature, this solution was left undisturbed for few days, given yellow crystals that were isolated (94 mg, 43\%). Found: C, 56.44; H, 4.72; N, 9.44\%. Calc. for $\left(\mathrm{C}_{21} \mathrm{H}_{20} \mathrm{~N}_{3} \mathrm{O}_{4} \mathrm{~V}\right)_{2} \cdot \mathrm{H}_{2} \mathrm{O}: \mathrm{C}, 57.54 ; \mathrm{H}, 4.83$; $\mathrm{N}, 9.59 \%{ }^{~}{ }^{\mathrm{H}} \mathrm{NMR}\left(300 \mathrm{MHz}, \mathrm{DMSO}-d_{6}, 25^{\circ} \mathrm{C}\right) \delta 9.22(\mathrm{~d}$, $\left.J 5.10 \mathrm{~Hz}, 1 \mathrm{H}, \mathrm{H}^{\mathrm{a}}\right), 8.65\left(\mathrm{~d}, J 4.50 \mathrm{~Hz}, 1 \mathrm{H}, \mathrm{H}^{\mathrm{a}^{\prime}}\right), 8.05(\mathrm{td}$, $\left.J 7.50,1.80 \mathrm{~Hz}, 1 \mathrm{H}, \mathrm{H}^{\mathrm{c}^{\prime}}\right), 7.67\left(\mathrm{~d}, J 7.80 \mathrm{~Hz}, 1 \mathrm{H}, \mathrm{H}^{\mathrm{d}^{\mathrm{d}}}\right), 7.56$ $\left(\mathrm{td}, J 7.50,1.80 \mathrm{~Hz}, 1 \mathrm{H}, \mathrm{H}^{\mathrm{c}}\right), 7.50\left(\mathrm{t}, J 6.60,6.30 \mathrm{~Hz}, \mathrm{H}^{\mathrm{b}^{\prime}}\right)$, 7.26-7.22 (m, 2H, $\mathrm{H}^{\mathrm{b}}$ and $\left.\mathrm{H}^{\mathrm{f}}\right), 6.98\left(\mathrm{~d}, J 2.10 \mathrm{~Hz}, 1 \mathrm{H}, \mathrm{H}^{\mathrm{e}}\right)$, $6.83\left(\mathrm{~d}, J 7.80 \mathrm{~Hz}, \mathrm{H}^{\mathrm{d}}\right), 5.07\left(\mathrm{~d}, J 12.00 \mathrm{~Hz}, 1 \mathrm{H}, \mathrm{CH}_{2}-\mathrm{N}-\mathrm{Ar}\right)$, 4.89 (d, $\left.J 15.00 \mathrm{~Hz}, 1 \mathrm{H}, \mathrm{CH}_{2}-\mathrm{N}-\mathrm{Ar}\right), 4.37$ (d, J $15.00 \mathrm{~Hz}$, $\mathrm{CH}_{2}-\mathrm{N}-\mathrm{Ar}$ ), 4.06 (d, J $\left.17.40 \mathrm{~Hz}, 1 \mathrm{H}, \mathrm{CH}_{2}-\mathrm{N}-\mathrm{Ar}\right), 3.94$ (d, $\left.J 12.00 \mathrm{~Hz}, \mathrm{CH}_{2}-\mathrm{N}-\mathrm{Ar}\right), 3.75$ (d, $J 17.40 \mathrm{~Hz}, 1 \mathrm{H}$, $\left.\mathrm{CH}_{2}-\mathrm{N}-\mathrm{Ar}\right), 2.12\left(\mathrm{~s}, 3 \mathrm{H}, \mathrm{CH}_{3}\right)$. IR $v_{\max } / \mathrm{cm}^{-1}(\mathrm{KBr}) \mathrm{v}(\mathrm{C}=\mathrm{O})$ $1660, v(\mathrm{C}=\mathrm{C}, \mathrm{C}=\mathrm{N}) 1610,1568,1471,1456$ and 1431 , $v(\mathrm{C}-\mathrm{O}) 1262, v(\mathrm{O}=\mathrm{V}=\mathrm{O}) 895$ and 875, $v(\mathrm{C}-\mathrm{H}) 760$.

\section{Synthesis of $\left[\mathrm{VO}_{2}(\right.$ Lox $\left.)\right](2)$}

The complex $\left[\mathrm{VO}_{2}(\operatorname{Lox})\right]$ was prepared by three different ways, according to Scheme 1, from the reaction of $\left[\mathrm{VO}(\mathrm{acac})_{2}\right]$ and the ligand HLox (ii); of $\left[\mathrm{VO}(\mathrm{acac})_{2}\right]$, $\mathrm{HL}$ and hydroxylamine (iii); and of $\left[\mathrm{VO}_{2}(\mathrm{~L})\right]$ with hydroxylamine (iv).

(ii). To a solution of HLox $(90 \mathrm{mg}, 0.25 \mathrm{mmol})$ in methanol $(30 \mathrm{~mL}),\left[\mathrm{VO}(\mathrm{acac})_{2}\right](66 \mathrm{mg}, 0.25 \mathrm{mmol})$ was added. The mixture was heated at $80^{\circ} \mathrm{C}$ under stirring for $30 \mathrm{~min}$ and then cooled to room temperature. Brown crystals were collected after leaving the solution resting undisturbed for few days (44 mg, 40\%). Found: C, 55.63; $\mathrm{H}, 4.73 ; \mathrm{N}, 12.30 \%$. Calc. for $\mathrm{C}_{21} \mathrm{H}_{21} \mathrm{~N}_{4} \mathrm{O}_{4} \mathrm{~V}: \mathrm{C}, 56.76 ; \mathrm{H}$, 4.76; N, $12.61 \%$. ${ }^{1} \mathrm{H}$ NMR (300 MHz, DMSO- $\left.d_{6}, 25^{\circ} \mathrm{C}\right)$ $\delta 9.20\left(\mathrm{~d}, J 5.34 \mathrm{~Hz}, 1 \mathrm{H}, \mathrm{H}^{\mathrm{a}}\right), 8.65\left(\mathrm{~d}, J 5.07 \mathrm{~Hz}, 1 \mathrm{H}, \mathrm{H}^{\mathrm{a}}\right)$, $8.00\left(\mathrm{~s}, 1 \mathrm{H}, \mathrm{H}^{\mathrm{g}}\right), 7.97\left(\mathrm{~d}, J 7.62 \mathrm{~Hz}, 1 \mathrm{H}, \mathrm{H}^{\mathrm{c}^{\prime}}\right), 7.60(\mathrm{~d}$, $\left.J 7.85 \mathrm{~Hz}, 2 \mathrm{H}, \mathrm{H}^{\mathrm{d}^{\prime}}\right), 7.58\left(\mathrm{~d}, J 7.61 \mathrm{~Hz}, 2 \mathrm{H}, \mathrm{H}^{\mathrm{c}}\right), 7.45(\mathrm{t}$, $\left.J 6.90,6.20 \mathrm{~Hz}, 1 \mathrm{H}, \mathrm{H}^{\mathrm{b}^{\prime}}\right), 7.23\left(\mathrm{t}, J 6.17,6.10 \mathrm{~Hz}, 1 \mathrm{H} ; \mathrm{H}^{\mathrm{b}}\right)$, $7.04\left(\mathrm{~d}, J 1.91 \mathrm{~Hz}, 1 \mathrm{H}, \mathrm{H}^{\mathrm{f}}\right), 6.92\left(\mathrm{~d}, J 2.07 \mathrm{~Hz}, 1 \mathrm{H}, \mathrm{H}^{\mathrm{e}}\right), 6.88$ $\left(\mathrm{d}, J 8.05 \mathrm{~Hz}, 1 \mathrm{H}, \mathrm{H}^{\mathrm{d}}\right), 5.11\left(\mathrm{~d}, J 12.14 \mathrm{~Hz}, 1 \mathrm{H}, \mathrm{CH}_{2}-\mathrm{N}-\mathrm{Ar}\right)$, 4.83 (d, J $\left.14.83 \mathrm{~Hz}, 1 \mathrm{H}, \mathrm{CH}_{2}-\mathrm{N}-\mathrm{Ar}\right), 4.33$ (d, J $14.93 \mathrm{~Hz}$, $1 \mathrm{H}, \mathrm{CH}_{2}-\mathrm{N}-\mathrm{Ar}$ ), 4.09 (d, J $17.63 \mathrm{~Hz}, 1 \mathrm{H}, \mathrm{CH}_{2}-\mathrm{N}-\mathrm{Ar}$ ), 3.88 (d, $\left.J 12.18 \mathrm{~Hz}, 1 \mathrm{H}, \mathrm{CH}_{2}-\mathrm{N}-\mathrm{Ar}\right), 3.75(\mathrm{~d}, J 17.56 \mathrm{~Hz}, 1 \mathrm{H}$, $\left.\mathrm{CH}_{2}-\mathrm{N}-\mathrm{Ar}\right), 2.11$ (s, $\left.3 \mathrm{H}, \mathrm{CH}_{3}\right)$; IR $v_{\max } / \mathrm{cm}^{-1}(\mathrm{KBr}) v(\mathrm{C}=\mathrm{C}$, $\mathrm{C}=\mathrm{N}) 1596,1473$ and 1440, $v(\mathrm{C}-\mathrm{O}) 1231, v(\mathrm{O}=\mathrm{V}=\mathrm{O}) 895$ and $854, v(\mathrm{C}-\mathrm{H}) 763$.

(iii). To a solution of HL (174 $\mathrm{mg}, 0.50 \mathrm{mmol})$ in methanol $(30 \mathrm{~mL}),\left[\mathrm{VO}(\mathrm{acac})_{2}\right](132 \mathrm{mg}, 0.50 \mathrm{mmol})$, hydroxylamine hydrochloride $(52 \mathrm{mg}, 0.75 \mathrm{mmol})$ and triethylamine $(0.14 \mathrm{~mL}, 1.0 \mathrm{mmol})$ were added, and the mixture heated to $80^{\circ} \mathrm{C}$ under stirring for $1 \mathrm{~h}$ and then cooled to room temperature. Brown crystals were collected after leaving the solution rest undisturbed for few days (111 mg, 50\%).

(iv). To a solution of $\mathbf{1}(50 \mathrm{mg}, 0.12 \mathrm{mmol})$ in methanol (30 mL), hydroxylamine hydrochloride $(12 \mathrm{mg}, 0.18 \mathrm{mmol}$ ) and triethylamine $(34 \mu \mathrm{L}, 0.24 \mathrm{mmol})$ were added, and the mixture heated to $80^{\circ} \mathrm{C}$ under stirring for $1 \mathrm{~h}$ and then cooled to room temperature. Brown crystals were collected after leaving the solution resting undisturbed for few days.

\section{Crystal structure determination}

$\mathrm{X}$-ray diffraction data collection for both complexes were performed on a Bruker-Kappa-CCD diffractometer (LdrX-UFF) using graphite-monochromatized MoK $\alpha$ radiation $(\lambda=0.71073 \AA)$ at room temperature. ${ }^{26}$ Final unit cell parameters were based on the refinement of randomly selected reflections positions (DIRAX programs) during PHICHI scanning. ${ }^{27,28}$ Data integration and scaling of the reflections were performed with the EVALCCD suite. ${ }^{28,29}$ Empirical multiscan absorption corrections using equivalent reflections were performed with the program SADABS. ${ }^{30}$ The molecular structures were solved by direct methods using the SHELXS-97 program. ${ }^{31}$ The positions of all atoms could be unambiguously assigned on consecutive difference Fourier maps. Refinements were performed using SHELXL-97 based on $\mathrm{F}^{2}$ through full-matrix least square routine. ${ }^{32}$ All but hydrogen atoms were refined with anisotropic atomic displacement parameters. Hydrogen 
atoms were added geometrically in the structure and further refined according to the riding model ${ }^{33}$ Crystal structure and refinement data for compounds $\mathbf{1}$ and $\mathbf{2}$ are summarized in Table S1. ORTEP of the structures are depicted in Figures 3 and $4 .{ }^{34}$ Relevant distances and angles are indicated in Table 2. Atomic coordinates and complete crystal structure results are given as supplementary material.

\section{Theoretical calculations}

Density functional calculations were carried out using the Gaussian03W molecular orbital package. ${ }^{35}$ Geometries were fully optimized (starting from the structure obtained after the X-ray diffraction data refinements) using the B3LYP functional with the standard 6-31G(d) basis set. ${ }^{26,37}$ NMR spectra for the optimized geometry were calculated using B3LYP/6-31G(d). Electronic spectra were calculated using the TD (time dependent) methodology available in Gaussian with the B3LYP/6-31+G(d) method.

\section{Reactivity studies}

The cyclohexane oxidation experiments followed typical procedures reported previously. ${ }^{15}$ Reactions were carried out in acetonitrile, using either $\mathrm{H}_{2} \mathrm{O}_{2}$ or $t$ - $\mathrm{BuOOH}$ as oxidant and the complexes $\mathbf{1}$ and $\mathbf{2}$ as catalysts. The catalyst:substrate:oxidant ratio was of $1: 1000: 1000$, were the catalyst concentration was kept at $7 \times 10^{-4} \mathrm{~mol} \mathrm{~L}^{-1}$. The reactions were carried out under inert atmosphere (argon) at room temperature in a sealed round-bottomed flask. The catalyst was dissolved in acetonitrile, the solution was deoxygenated with argon and the oxidant was added with a syringe. Catalytic reactions were triggered by the addition of cyclohexane under stirring. After $24 \mathrm{~h}$ it was quenched by addition of an aqueous solution of $\mathrm{Na}_{2} \mathrm{SO}_{4}\left(0.4 \mathrm{~mol} \mathrm{~L}^{-1}\right)$ and extracted with $10 \mathrm{~mL}$ of diethyl ether. The organic layers were combined, dried over anhydrous $\mathrm{Na}_{2} \mathrm{SO}_{4}$ and analyzed by GC (gas chromatography). Control experiments were carried out in the same conditions in the absence of catalyst. The products were determined by separated injection of standard grade cyclohexanol and cyclohexanone, and confirmed by GC-MS. Cyclohexylhydroperoxide was identified as the product with higher retention time $(14.0 \mathrm{~min})$ and confirmed by GC-MS.

\section{Results and Discussion}

\section{Syntheses}

The ligand HL was prepared following a procedure reported previously, and characterized by ${ }^{1} \mathrm{H}$ NMR. The $\mathrm{H}_{2}$ Lox was obtained by a reaction between HL and hydroxylamine, as a greenish viscous oil with $80 \%$ yield. The conversion of the aldehyde of HL to the oxime in $\mathrm{H}_{2}$ Lox was confirmed by IR and ${ }^{1} \mathrm{H}$ NMR spectroscopy. The most relevant information from IR data is the presence of an intense peak at $1678 \mathrm{~cm}^{-1}$ in the spectrum of $\mathrm{HL}$, assigned to the $\mathrm{C}=\mathrm{O}$ stretching of benzaldehyde, which is absent in the spectrum of $\mathrm{H}_{2}$ Lox (Figure 1). The ${ }^{1} \mathrm{H}$ NMR spectra show that the signal of $\mathrm{H}^{\mathrm{g}}$ in $\mathrm{HL}$ shifts from $\delta 10.43$ to $8.40 \mathrm{ppm}$ in the spectrum of HLox, due to the conversion of $\mathrm{HC}(\mathrm{R})=\mathrm{O}$ into $\mathrm{HC}(\mathrm{R})=\mathrm{NOH}$. The full assignment of $\mathrm{HL}$ and HLox NMR spectra is shown in Figure 2.
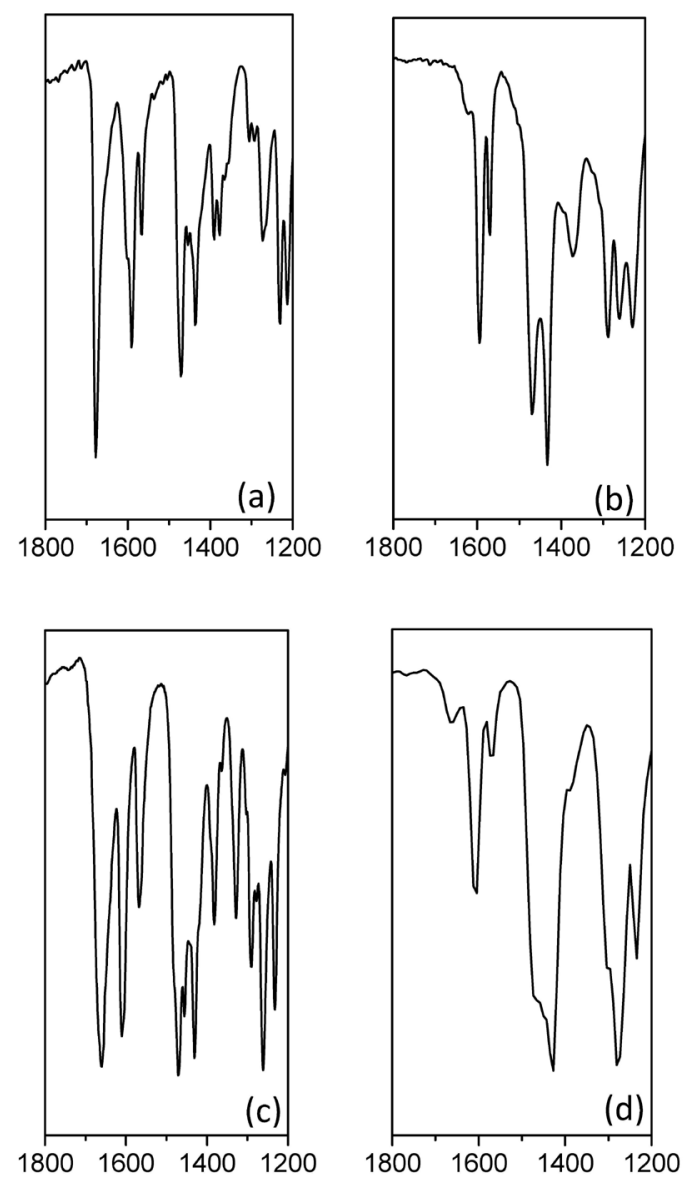

Figure 1. Selected IR spectra $\left(\mathrm{KBr}\right.$, transmittance / \% vs. frequency / $\left.\mathrm{cm}^{-1}\right)$ of HL (a), $\mathrm{H}_{2} \operatorname{Lox}$ (b), $\mathbf{1}$ (c) and $\mathbf{2}$ (d).

The reaction of $\mathrm{HL}$ with $\left[\mathrm{VO}(\mathrm{acac})_{2}\right]$ in methanol produced 1 as yellow single crystals after slow evaporation of the mother solution. Complex 2 was prepared by three different procedures, according to Scheme 1. In all cases, brown single crystals were obtained after slow evaporation of the mother solution. Besides the same color and morphology, IR and ${ }^{1} \mathrm{H}$ NMR analyses confirmed the same composition for the solids obtained from the three procedures. Figures 1 and 2 show the main spectral 


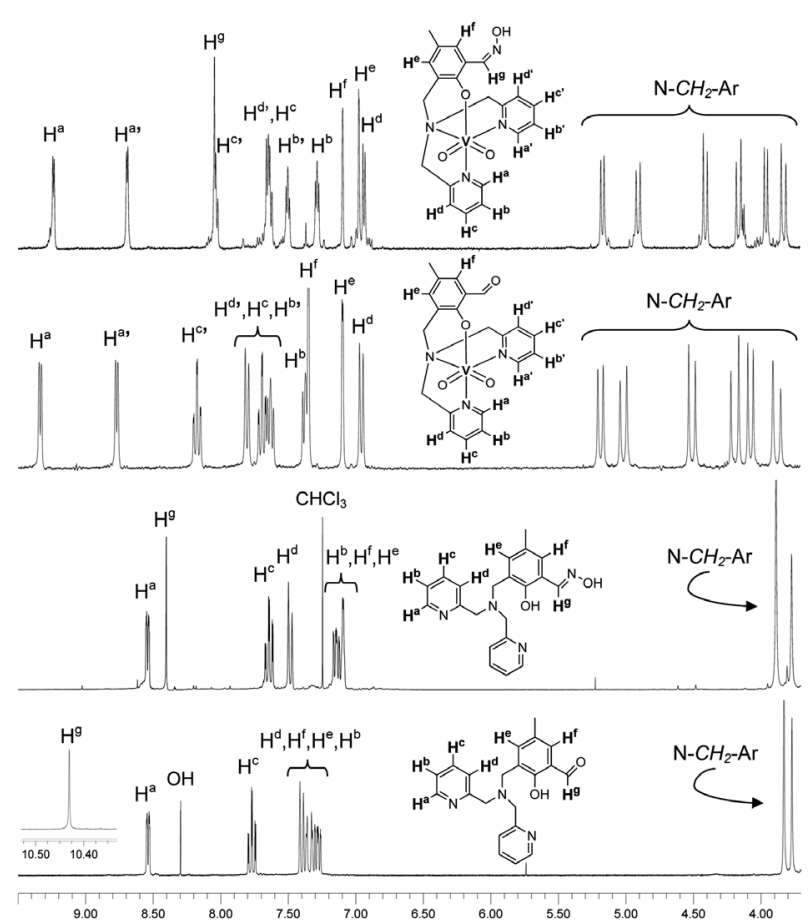

Figure 2. ${ }^{1} \mathrm{H}$ RMN spectra of $\mathrm{HL}$ and $\mathrm{H}_{2} \mathrm{Lox}$ in $\mathrm{CDCl}_{3}$, and of $\mathbf{1}$ and $\mathbf{2}$ in DMSO- $d_{6}$ (from the bottom to the top, respectively).

remarks for complexes $\mathbf{1}$ and $\mathbf{2}$ compared with their precursor ligands HL and HLox. Although changes in frequencies of almost all peaks were observed in IR spectra after complexation, the general feature of ligands spectra remained in their respective complexes. The most drastic change in the ligands spectra, however, was observed by ${ }^{1} \mathrm{H}$ NMR after coordination. For the free ligands, the hydrogen atoms $\mathrm{H}^{\mathrm{a}}-\mathrm{H}^{\mathrm{d}}$ are equivalent to $\mathrm{H}^{\mathrm{a}}$ '- $\mathrm{H}^{\mathrm{d}}$, as the two pyridine rings have similar chemical environments. The same happens with the $-\mathrm{CH}_{2}-$ hydrogen atoms, observed as two singlet peaks between $\delta 3.5$ and $4.0 \mathrm{ppm}$. For the complexes, each hydrogen atom of the ligand, aliphatic and aromatic, can be associated with an individual peak in the spectra. This fact indicates that after complexation, one single conformation of the ligand is arranged around the metal center. As electron density is transferred to the metal through the $\mathrm{N}, \mathrm{O}$-donor atoms, the chemical environment of each $\mathrm{H}$ atom is now different. The full assignment of the spectra shown in Figure 2 was performed according to 2D COSY experiments of all compounds and calculation of the ${ }^{1} \mathrm{H}$ NMR spectrum for complex $\mathbf{1}$.

\section{$X$-ray structures}

The molecular structures of complexes $\mathbf{1}$ and $\mathbf{2}$ consist of identical distorted octahedral environments, in which the ligands $\mathrm{L}^{-}$and $\mathrm{Lox}^{-}$, respectively, are coordinated around the cis-dioxo vanadium center. The three nitrogen atoms, from the two pyridines and the tertiary amine, are arranged in a facial configuration, in such a way that pyridine-N1 is trans to phenol-O1, pyridine-N2 is trans to oxo-O2 and the tertiary-N3 is trans to oxo-O3. In both complexes, the aldehyde and oxime groups remain uncoordinated. The asymmetric unit of $\mathbf{1}$ contains two molecules of complex and one water molecule, connected by hydrogen bonds (Figure 3). The aldehyde-O4B atom of molecule B binds one of the $\mathrm{H}$ atoms of the water, while the other water hydrogen atom binds the oxo-O2A atom of molecule A. For complex $\mathbf{2}$, the crystal packing is assured by intramolecular hydrogen bonds, in which the hydrogen atom of the oxime of one molecule binds the oxo-O2 atom of the next one (Figure 4). These hydrogen bonds direct the crystalline packing towards [100] direction. Table 1 summarizes the hydrogen-bonds for $\mathbf{1}$ and $\mathbf{2}$.

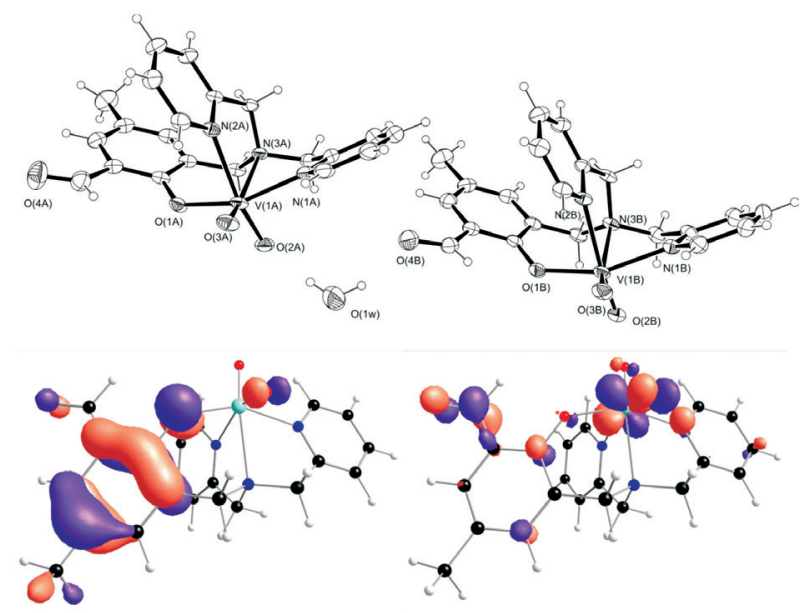

Figure 3. ORTEP ${ }^{32}$ (top) and frontier orbitals HOMO (bottom, left) and LUMO (bottom, right) of complex 1.

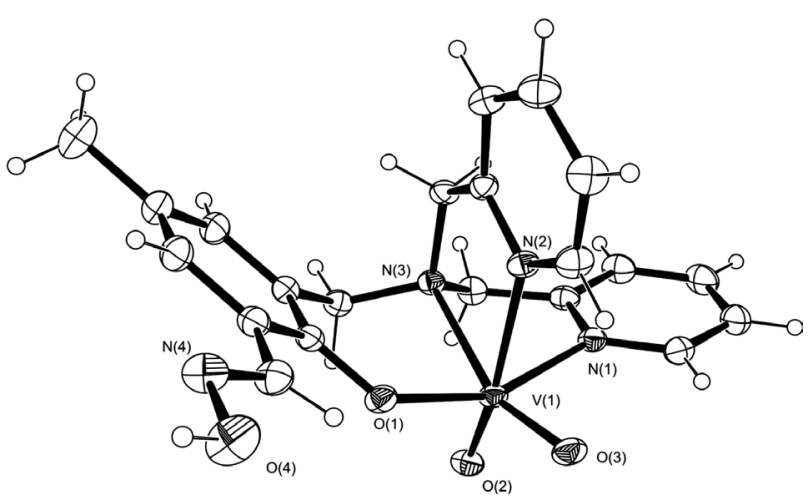

Figure 4. ORTEP ${ }^{32}$ of complex 2.

As can be observed in Table 2, the bond lengths and angles around the metal center are very similar for both complexes. According to information retrieved from the 
Table 1. Hydrogen-bond geometry for $\mathbf{1}$ and $\mathbf{2}\left(\AA,^{\circ}\right)$

\begin{tabular}{lcccc}
\hline$D-\mathrm{H} \cdots A$ & $D-\mathrm{H}$ & $\mathrm{H} \cdots A$ & $D \cdots A$ & $D-\mathrm{H} \cdots A$ \\
{$\left[\mathrm{VO}_{2}(\mathrm{~L})\right]$} & & & & \\
\hline $\mathrm{O} 1 \mathrm{~W}-\mathrm{H} 1 \mathrm{~W} 2 \cdots \mathrm{O} 4 \mathrm{~B}$ & 0.86 & 2.06 & $2.864(5)$ & 155 \\
$\mathrm{O} 1 \mathrm{~W}-\mathrm{H} 1 \mathrm{~W} 1 \cdots \mathrm{O} 2 \mathrm{~A}$ & 0.86 & 1.95 & $2.809(5)$ & 170 \\
\hline$\left[\mathrm{VO}_{2}(\mathrm{Lox})\right]$ & & & & \\
\hline $\mathrm{O} 4-\mathrm{HOx} \cdots \mathrm{O} 2$ & 0.82 & 2.00 & $2.794(3)$ & 163 \\
\hline
\end{tabular}

Table 2. Bond lengths $(\AA)$ and angles $\left(^{\circ}\right)$ for $\mathbf{1}$ and 2

\begin{tabular}{lcccc}
\hline \multirow{2}{*}{ Complex } & \multicolumn{3}{c}{$\left[\mathrm{VO}_{2}(\mathrm{~L})\right](\mathbf{1})$} & [VO \\
\cline { 2 - 4 } & Molec. A & Molec. B & B3LYP & $(2)$ \\
\hline V1-O1 & $1.949(3)$ & $1.947(3)$ & 1.908 & $1.932(2)$ \\
V1-O2 & $1.654(3)$ & $1.642(3)$ & 1.609 & $1.668(6)$ \\
V1-O3 & $1.632(3)$ & $1.639(3)$ & 1.607 & $1.631(6)$ \\
V1-N1 & $2.150(4)$ & $2.135(4)$ & 2.191 & $2.151(2)$ \\
V1-N2 & $2.306(3)$ & $2.325(3)$ & 2.373 & $2.286(2)$ \\
V1-N3 & $2.312(3)$ & $2.315(3)$ & 2.421 & $2.304(7)$ \\
O2-V1-O3 & $106.97(2)$ & $106.59(2)$ & 108.99 & $105.97(9)$ \\
O1-V1-N1 & $156.69(1)$ & $156.44(2)$ & 153.46 & $156.85(7)$ \\
N1-V1-N3 & $72.79(1)$ & $72.99(1)$ & 71.62 & $72.99(7)$ \\
O3-V1-N2 & $89.99(1)$ & $88.84(1)$ & 90.26 & $88.65(8)$ \\
N3-V1-N2 & $72.31(1)$ & $72.29(1)$ & 70.09 & $73.07(7)$ \\
\hline
\end{tabular}

Cambridge Structural Database (CSD, Conquest) ${ }^{38}$ for a vanadium cis-dioxo complex in an octahedral geometry, the average angle $\mathrm{O}=\mathrm{V}=\mathrm{O}$ is $105.8(9)^{\circ}$, and the average distance for $\mathrm{V}_{-} \mathrm{N}_{\text {pyridine }}$ is $2.22(9) \AA$, for $\mathrm{V}-\mathrm{O}_{\text {phenol }}$ is $1.94(5) \AA$, for $\mathrm{V}=\mathrm{O}$ is $1.64(2) \AA$ and for $\mathrm{V}-\mathrm{N}_{\text {amine }}$ is 2.26(9) $\AA$. These values are in a good agreement with those found for complexes $\mathbf{1}$ and $\mathbf{2}$ (Table 2). It should be noted, however, that in both complexes the V1-N1 bond is about $0.17 \AA$ shorter than the V1-N2 bond, despite the fact that both are $\mathrm{V}-\mathrm{N}_{\text {pyridine }}$ bonds. This difference can be explained by the influence of the ligand trans to the pyridine nitrogen atoms. The $\mathrm{N} 1$ atom has one phenolic oxygen in the trans position, while $\mathrm{N} 2$ is trans to an oxo group. As the $\mathrm{V}=\mathrm{O}$ bond is much shorter that the $\mathrm{V}-\mathrm{O}_{\text {phenol }}$, the bond distance of the ligand trans to the former (V-N2) is longer than the other $(\mathrm{V}-\mathrm{N} 1)$. These results are reinforced by the B3LYP/6-31G(d) calculations for $\left[\mathrm{VO}_{2}(\mathrm{~L})\right]$.

\section{Electronic spectra}

UV-Visible spectra, in DMSO, show the presence of absorptions with maxima at $370 \mathrm{~nm}\left(\varepsilon=9 \times 10^{3} \mathrm{~mol} \mathrm{~L}^{-1} \mathrm{~cm}^{-1}\right)$ for $\mathbf{1}$ and $333 \mathrm{~nm}\left(\varepsilon=9 \times 10^{3} \mathrm{~mol} \mathrm{~L}^{-1} \mathrm{~cm}^{-1}\right)$ for 2 . A shoulder in 260-270 $\mathrm{nm}$ was also observed for both compounds. As the vanadium center is in a +5 oxidation state $\left(3 \mathrm{~d}^{0}\right.$ configuration), what is in agreement with the ${ }^{1} \mathrm{H}$ NMR spectra typical of diamagnetic species (Figure 2), ligand field transitions are not expected. Therefore, the observed bands should be related to LMCT and intra-ligand charge transfer transitions. To get a better insight into the UV-Vis spectra, the time dependent (TD) approach available in Gaussian was employed to calculate the electronic transitions for $\left[\mathrm{VO}_{2}(\mathrm{~L})\right]$. The calculated spectra at the B3LYP/6-31+G(d) level revealed two intense bands at 386 and $356 \mathrm{~nm}$, which may be superimposed in the observed absorption maxima at $370 \mathrm{~nm}$. The first band, at $386 \mathrm{~nm}$, is assigned to the HOMO $\rightarrow$ LUMO transition, which correspond to a LMCT process involving a $\mathrm{p} \pi$ orbital on the aromatic phenolate ring (the HOMO) and one empty $3 \mathrm{~d}$ orbital on the metal (the LUMO). The second band, at $356 \mathrm{~nm}$, is attributed to an intraligand transition involving the HOMO and the antibonding orbital of the carbonyl group. Frontier orbitals for $\mathbf{1}$ are depicted in Figure 3. In the region between 259 and $275 \mathrm{~nm}$ several bands of medium to high intensity are predicted, most of them involving contributions of several transitions, mainly LMCT. Kwiatkowski et al. ${ }^{8}$ reported a series of amino/imino-phenolate oxovanadium $(\mathrm{V})$ complexes with similar spectral features. For these complexes, the lowest energy bands, in the 349-404 $\mathrm{nm}$ range, were assigned to LMCT transitions involving the $p \pi$ orbital of phenolate and the empty $3 \mathrm{~d}$ orbital of the metal. The highest energy bands, observed in approximately $325 \mathrm{~nm}$, were assigned to intraligand $\pi-\pi *$ transitions.

\section{Redox properties}

Cyclic voltammograms (CV) of complexes $\mathbf{1}$ and 2, in DMSO, show two reduction processes, as can be observed in Figure 5. All potentials are reported versus the ferrocene/ferrocinium $\left(\mathrm{Fc} / \mathrm{Fc}^{+}\right)$redox couple, used as internal reference.

The first process is an irreversible wave with peak potential at $-1.89 \mathrm{~V}$ for $\mathbf{1}$ and $-1.96 \mathrm{~V}$ for $\mathbf{2}$. The second process, with half wave potentials at $-2.19 \mathrm{~V}(\Delta \mathrm{E}=0.11 \mathrm{~V})$ for $\mathbf{1}$ and $-2.23 \mathrm{~V}(\Delta \mathrm{E}=0.16 \mathrm{~V})$ for $\mathbf{2}$, is better described as quasi-reversible. It was also observed for $\mathbf{1}$ a low intensity irreversible wave at $-0.68 \mathrm{~V}$, which seems to be related to the reduction peak at $-1.89 \mathrm{~V}$, as it does not appear when the scan direction is inverted, starting from $-1.40 \mathrm{~V}$ (see Figure S2). This wave is absent in the CV of complex $\mathbf{2}$, which has, however, an intense irreversible peak at $+0.58 \mathrm{~V}$ that is not observed for 1. Cyclic voltammograms of the ligands were also measured under similar conditions (Figure S3). While $\mathrm{H}_{2}$ Lox did not present any redox response in the negative segments of the $\mathrm{CV}$, an irreversible peak at $-2.14 \mathrm{~V}$ was observed for HL. Based on these data, 

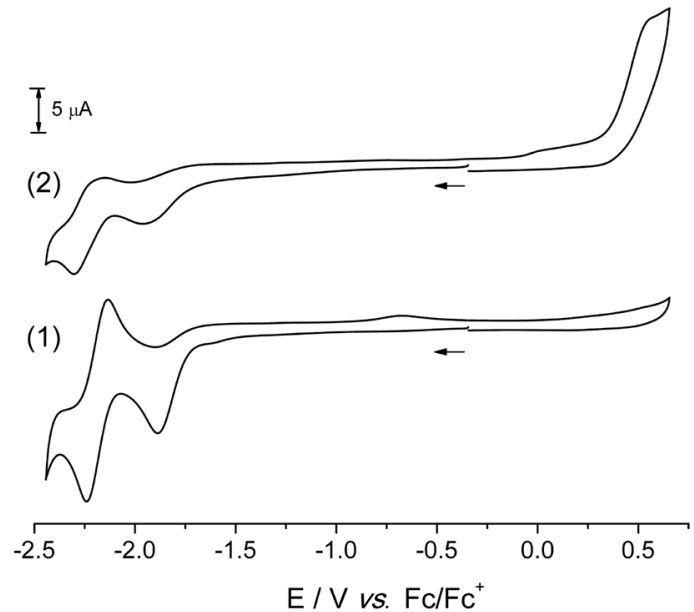

Figure 5. Cyclic voltammograms of complexes $\mathbf{1}$ (bottom) and $\mathbf{2}$ (top) in a DMSO/TBAPF $6.1 \mathrm{~mol} \mathrm{~L}^{-1}$ solution, scan rate $=0.1 \mathrm{~V} \mathrm{~s}^{-1}$, working electrode $=$ glassy carbon, reference $=\mathrm{Ag} / \mathrm{AgCl}\left(\mathrm{DMSO} / \mathrm{TBAPF}_{6}\right.$ $\left.0.1 \mathrm{~mol} \mathrm{~L}^{-1}\right)$, auxiliary = platinum wire and ferrocene as internal reference.

the first irreversible reduction wave observed for complexes $\mathbf{1}$ and $\mathbf{2}$ is tentatively assigned to be centered in the ligand, while the more negative quasi-reversible reduction process is tentatively assigned to the $\mathrm{V}^{\mathrm{V}} / \mathrm{V}^{\mathrm{IV}}$ couple. The slightly more negative reduction potentials of complex $\mathbf{2}$ could be related to the presence of the oxime group, which has a weaker electron withdrawing capability compared with the aldehyde carbonyl present in complex $1 .{ }^{39} \mathrm{CV}$ experiments using dichloromethane as solvent were also carried out for $\mathbf{1}$, with identical results to those obtained in DMSO. However, experiments in this solvent were not possible for complex 2 due to its low solubility.

\section{Catalytic oxidation of cyclohexane}

In order to investigate the potential use of complexes 1 and $\mathbf{2}$ as catalysts in oxidative processes, their reactivities were preliminary investigated through the oxidation of cyclohexane (Scheme 2). In a typical experiment, cyclohexane was oxidized in the presence of the desired complex and $\mathrm{H}_{2} \mathrm{O}_{2}$ or $t$ - $\mathrm{BuOOH}$. After $24 \mathrm{~h}$ of reaction, the products cyclohexanol $(\mathrm{Cy}-\mathrm{OH})$, cyclohexanone $(\mathrm{Cy}=\mathrm{O})$, cyclohexylhydroperoxide (Cy-OOH) and/or cyclohexyltert-buthylhydroperoxide (Cy-OO- $t$-Bu) were detected, and the results are summarized in Table 3.

Complex 1 is the most active catalyst, presenting an overall conversion of $12 \%$ when the oxidant is $\mathrm{H}_{2} \mathrm{O}_{2}$ and only $5.7 \%$ employing $t$ - $\mathrm{BuOOH}$. For complex $\mathbf{2}$, the overall conversion values are 5.7 and $2.1 \%$, respectively, for the same oxidants. According to Table 3 , the oxidation reactions exhibited better results when the oxidant was $\mathrm{H}_{2} \mathrm{O}_{2}$, probably because is a stronger oxidant than $t-\mathrm{BuOOH}$, since their initial concentrations were kept the same to assure the

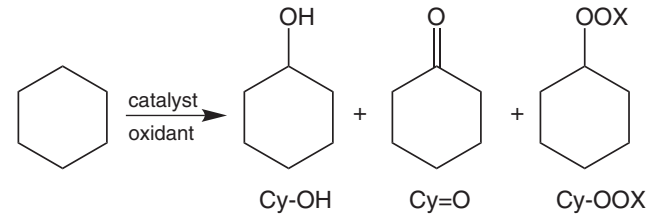

Scheme 2. Cyclohexane oxidation products ( $\mathrm{X}=\mathrm{H}$ or $t$-butyl).

Table 3. Product distribution for the cyclohexane oxidation after $24 \mathrm{~h}$

\begin{tabular}{|c|c|c|c|c|c|}
\hline Catalyst & Oxidant & Product & $\begin{array}{c}\text { Overall } \\
\text { conversion }\end{array}$ & Turnover & Selectivity \\
\hline \multirow{6}{*}{1} & $\mathrm{H}_{2} \mathrm{O}_{2}$ & $\mathrm{Cy}-\mathrm{OH}$ & & & $13 \%$ \\
\hline & & $\mathrm{Cy}=\mathrm{O}$ & $12 \%$ & 137 & $14 \%$ \\
\hline & & $\mathrm{Cy}-\mathrm{OOH}$ & & & $73 \%$ \\
\hline & $t-\mathrm{BuOOH}$ & $\mathrm{Cy}-\mathrm{OH}$ & & & $0 \%$ \\
\hline & & $\mathrm{Cy}=\mathrm{O}$ & $1.4 \%$ & 15 & $14 \%$ \\
\hline & & Cy-OO-t-Bu & & & $86 \%$ \\
\hline \multirow{6}{*}{2} & $\mathrm{H}_{2} \mathrm{O}_{2}$ & $\mathrm{Cy}-\mathrm{OH}$ & & & $17 \%$ \\
\hline & & $\mathrm{Cy}=\mathrm{O}$ & $5.7 \%$ & 62 & $12 \%$ \\
\hline & & $\mathrm{Cy}-\mathrm{OOH}$ & & & $71 \%$ \\
\hline & $t-\mathrm{BuOOH}$ & $\mathrm{Cy}-\mathrm{OH}$ & & & $0 \%$ \\
\hline & & $\mathrm{Cy}=\mathrm{O}$ & $2.1 \%$ & 23 & $42 \%$ \\
\hline & & Cy-OO-t-Bu & & & $58 \%$ \\
\hline
\end{tabular}

ratio catalyst:substrate:oxidant as 1:1000:1000. In fact, this same behavior has been observed before and may be one of the reasons of the overall conversion values using $\mathrm{H}_{2} \mathrm{O}_{2}$ to be about nine times larger compared with $t \mathrm{BuOOH}$, for complex 1. ${ }^{16,18,40-42}$ However, it cannot be excluded that acetonitrile plays an important role in this process because of a competition between the solvent and the hydrocarbon by an oxidizing species, which can be generated with both oxidants. ${ }^{16,43}$ Although the overall conversion values for both complexes are low, they showed to be selective to the intermediates cyclohexylhydroperoxide $(\mathrm{Cy}-\mathrm{OOH})$ or cyclohexyl-tert-butylhydroperoxide (Cy-OO- $t$ - $\mathrm{Bu})$, depending if the oxidant was $\mathrm{H}_{2} \mathrm{O}_{2}$ or $t-\mathrm{BuOOH}$. For complex $\mathbf{1}$, the intermediate was selectively formed with yields of 73 and $86 \%$ when the oxidants were, respectively, $\mathrm{H}_{2} \mathrm{O}_{2}$ and $t$-BuOOH. For complex 2 , the yields were $73 \%$ when the oxidant was $\mathrm{H}_{2} \mathrm{O}_{2}$, and $58 \%$ when the oxidant was $t$ - $\mathrm{BuOOH}$. The turnover number for $\mathbf{1}$ is about twice the value observed for $\mathbf{2}$, while both complexes present similar turnover numbers when $t$ - $\mathrm{BuOOH}$ is used. These results are comparable with those previously reported for a $\mathrm{V}^{\mathrm{IV}} \mathrm{O}$ complex in a $\mathrm{N}_{3} \mathrm{O}_{3}$ environment and for a dinuclear $\mathrm{Cu}^{\mathrm{II}}$ complex. ${ }^{16,18}$ Despite the low overall conversion presented by complexes $\mathbf{1}$ and $\mathbf{2}$, it is higher than the corresponding uncatalyzed reactions which lead to less than $0.5 \%$ of overall conversion and selectivity to cyclohexylhydroperoxide or cyclohexyl-tert-butylhidroperoxide. Considering that these experiments were carried out at $1 \mathrm{~atm}$ pressure, room 
temperature, with no co-catalysts, and that the intermediates selectively formed are easily converted to cyclohexanol, cyclohexanone and adipic acid upon reduction, which are very important to the production of Nylon- 6 and Nylon-6,6, the complexes can be considered as quite efficient catalysts.

\section{Conclusions}

A novel tripodal ligand presenting an oxime pendant group (HLox) was successfully synthesized from the precursor ligand containing an aldehyde function (HL). Both HLox and HL were employed in the syntheses of two novel $\mathrm{V}^{\mathrm{v}}$ complexes, $\mathbf{1}$ and $\mathbf{2}$, which were also characterized as cis-dioxo $\mathrm{V}^{\mathrm{V}}$ systems. It was demonstrated that complex 2 can be prepared by three different pathways: from HLox, from $\mathrm{HL}$ and from complex $\mathbf{1}$. Complexes $\mathbf{1}$ and $\mathbf{2}$ presented overall conversions towards the cyclohexane oxidation between 5.7 and $12 \%$ using the friendly oxidant $\mathrm{H}_{2} \mathrm{O}_{2}$, with high selectivity (up to $85 \%$ ) to the cyclohexylhydroperoxide intermediate in mild conditions ( $1 \mathrm{~atm}$ and room temperature). The overall conversion, turnover number and selectivity obtained for complexes $\mathbf{1}$ and $\mathbf{2}$ are in the range of those values found for other oxovanadium complexes previously reported. ${ }^{10,16,19,22}$

\section{Supplementary Information}

Crystallographic data have been deposited at the Cambridge Crystallographic Data Centre (deposition numbers CCDC 772836 (1) and CCDC 772836 (2). Copies of available material can be obtained by request to CCDC, 12 Union Road, Cambridge CB2 1EZ, UK (fax 44-1223-336033 or e-mail: deposit@ccdc.cam.ac.uk).

\section{Acknowledgments}

We thank the financial support conceived from CNPq, FAPERJ, FINEP, PIBIC-UFF, and the X-Ray Diffraction Laboratory at Universidade Federal Fluminense (LdrX-UFF) for the data collection.

\section{References}

1. Vilter, H.; Bot. Mar. 1983, 26, 451.

2. Vilter, H.; Phytochem. 1984, 23, 1387.

3. Soedjak, H. S.; Butler, A.; Inorg. Chem. 1990, 29, 5015.

4. Butler, A.; Walker, J. V.; Chem. Rev. 1993, 93, 1937.

5. Rehder, D.; Coord. Chem. Rev. 1999, 182, 297; Colpas, G. J.; Hamstra, B. J.; Kampf, J. W.; Pecoraro, V. L.; J. Am. Chem. Soc. 1996, 118, 3469; Colpas, G. J.; Hamstra, B. J.; Kampf, J. W.; Pecoraro, V. L.; J. Am. Chem. Soc. 1994, 116, 3627.
6. Hamstra, B. J.; Colpas, G. J.; Pecoraro V. L.; Inorg. Chem. 1998, 37, 949.

7. Sun, J.; Zhu, C.; Dai, Z.; Yang, M.; Pan, Y.; Hu, H.; J. Org. Chem. 2004, 69, 8500; Blum, S. A.; Bergman, R. G.; Ellman, J. A.; J. Org. Chem. 2003, 68, 150.

8. Kwiatkowski, E.; Romanowski, G.; Nowicki, W.; Kwiatkowski, M.; Suwinska, K.; Polyhedron 2003, 22, 1009.

9. Mimoun, H.; Mignard, M.; Brechot, P.; Saussine, L.; J. Am. Chem. Soc. 1986, 108, 3711.

10. Mimoun, H.; Saussine, L.; Daire, E.; Postel, M.; Fischer, J.; Weiss, R.; J. Am. Chem. Soc. 1983, 105, 3101.

11. Shulpin, G. B.; Attanasio, D.; Suber, L.; J. Catal. 1993, 142, 147; Bonchio, M.; Conte, V.; Di Furia, F.; Modena, G.; J. Org. Chem. 1989, 54, 4368; Conte, V.; Di Furia, F.; Modena, G.; J. Org. Chem. 1988, 53, 1665.

12. Secco, F.; Inorg. Chem. 1980, 19, 2722.

13. Bhattacharjee, M. N.; Chaudhuri, M. K.; Islam, N. S.; Inorg. Chem. 1989, 28, 2420.

14. Saji, P. V.; Ratnasamy, C.; Gopinathan, S.; US pat 6,392,093B1, 2002.

15. Yuan, Y.; Ji, H.; Chen, Y.; Han, Y.; Song, X.; She, Y.; Zhong, R.; Org. Process Res. Dev. 2004, 8, 418.

16. Fernández, T. L.; Souza, E. T.; Visentin, L. C.; Santos, J. V.; Mangrich, A. S.; Faria, R. B.; Antunes, O. A. C.; Scarpellini, M.; J. Inorg. Biochem. 2009, 103, 474.

17. Silva, A. C.; Fernández, T. L.; Carvalho, M. F. N.; Herbst, M. H.; Bordinhão, J.; Horn Jr, A.; Wardell, J. L.; Oestreicher, E. G.; Antunes, O. A. C.; Appl. Catal., A 2007, 317, 154.

18. Martins, L. R.; Souza, E. T.; Fernández, T. L.; Souza, B.; Rachinski, S.; Pinheiro, C. B.; Faria, R. B.; Casellato, A.; Machado, S. P.; Mangrich, A. S.; Scarpellini, M.; J. Braz. Chem. Soc. 2010, 21, 1218.

19. Silva, T. F.; Luzyanin, K. V.; Kirillova, M. V.; Silva, M. F. G.; Martins, L. M. D. R. S.; Pombeiro, A. J. L.; Adv. Synth. Catal. 2010, 352, 171.

20. Kirillova, M. V.; Kuznetsov, M. L.; Romakh, V. B.; Shul'pina, L. S.; Silva, J. J. R. F.; Pombeiro, A. J. L.; Shulpin, G. B.; J. Catal. 2009, 267, 140.

21. Baran, E. J.; J. Inorg. Biochem. 2000, 80, 1.

22. Reis, P. M.; Silva, J. A. L.; Silva, J. J. R. F.; Pombeiro, A. J. L.; Chem. Commun. 2000, 1845.

23. Butler, A.; Clague, M. J.; Meister, G. E.; Chem. Rev. 1994, 94 , 625.

24. Gagne, R. R.; Koval, C. A.; Lisensky, G. C.; Inorg. Chem. 1980, 19, 2854.

25. Karsten, P.; Neves, A.; Bortoluzzi, A.J.; Lanznaster, M.; Drago, V.; Inorg. Chem. 2002, 41, 4624; Uozumi, S.; Furutachi, H.; Ohba, M.; Okawa, H.; Fenton, D. E.; Shindo, K.; Murata, S.; Kitko, D. J.; Inorg. Chem. 1998, 37, 6281.

26. Nonius; COLLECT, Nonius BV: Delft, The Netherlands, 1998.

27. Duisenberg, A. J. M.; J. Appl. Crystallogr. 1992, 25, 92. 
28. Duisenberg, A. J. M.; Hooft, R. W. W.; Schreurs, A. M. M.; Kroon, J.; J. Appl. Crystallogr. 2000, 33, 893.

29. Duisenberg, A. J. M.; Kroon-Batenburg, L. M. J.; Schreurs, A. M. M.; J. Appl. Crystallogr. 2003, 36, 220.

30. Sheldrick, G. M.; SADABS, Program for Empirical Absorption Correction of Area Detector Data, University of Göttingen, Germany, 1996.

31. Sheldrick, G. M.; SHELXS-97; Program for Crystal Structure Solution, University of Göttingen: Germany, 1997.

32. Sheldrick, G. M.; SHELXL-97; Program for Crystal Structure Refinement, University of Göttingen: Germany, 1997.

33. Johnson, C. K. Crystallographic Computing, Ahmed: Copenhagen, Munksgaard, 1970, 207-219.

34. Farrugia, L. J.; J. Appl. Crystallogr. 1997, 30, 565.

35. Gaussian 03, Revision B.02; Frisch, M. J.; Trucks, G. W.; Schlegel, H. B.; Scuseria, G. E.; Robb, M. A.; Cheeseman, J. R.; Montgomery, J. A.; Vreen Jr., T.; Kudin, K. N.; Burat, J. C.; Millam, J. M.; Iyengar, S. S.; Tomsi, J.; Barone, V.; Mennucci, B.; Cossi, M.; Scalmani, G.; Rega, N.; Petersson, G. A.; Nakatsuji, H.; Hada, M.; Ehara, M.; Toyota, K.; Fukua, R.; Hasegawa, J.; Ishida, M.; Nakajim, T.; Honda, Y.; Kitao, O.; Nakai, H.; Klene, M.; Li, X.; Knox, J. E.; Hratchian, H. P.; Cross, J. B.; Adamo, C.; Jaramillo, J.; Gomperts, R.; Stratmann, R. E.; Yazyev, O.; Austin, A. J.; Cammi, R.; Pomelli, C.; Ochteski, J. W.; Ayala, P. Y.; Morokuma, K.; Voth, G. A.; Salvador, P.; Dannenberg, J.
J.; Zakrzewski, V. G.; Dapprich, S.; Daniels, A. D.; Strain, M. C.; Faras, O.; Malick, D. K.; Rabu, A. D.; Raghavachari, K.; Foresman, J. B.; Ortiz, J. V.; Cui, Q.; Baboul, A. G.; Clifford, S.; Cioslowski, J.; Stefanov, B. B.; Liu, G.; Liashenko, A.; Piskorz, P.; Komaromi, I.; Martin, R. L.; Fox, D. J.; Keith, T.; Al-Laham, M. A.; Peng, C.; Nanayakkra, A.; Challacombe, M.; Gill, P. M. W.; Johnson, B.; Chen, W.; Wong, M. W.; Gonzalez, C.; Pople, J. A.; Gaussian, Inc., Pittsburg P. A., 2003.

36. Beck, A. D.; J. Chem. Phys. 1993, 98, 5648.

37. Hariharan, P. C.; Pople, J. A.; Theor. Chim. Acta 1973, $28,213$.

38. Allen, F. H.; Acta Crystallogr., Sect. B: Struct. Sci. 2002, 58, 380; Bruno, J.; Cole, J. C.; Edgington, P. R.; Kessler, M.; Macrae, C. F.; McCabe, P.; Pearson. J.; Taylor, R.; Acta Crystallogr., Sect. B: Struct. Sci.2002, 58, 389.

39. Lanznaster, M.; Neves, A.; Bortoluzzi, A. J.; Assumpção, A. M. C.; Vencato, I.; Machado, S. P.; Drechsel, S. M.; Inorg. Chem. 2006, 45, 1005.

40. Shul'pin, G. B.; Kozlov, Y. N.; Org. Biomol. Chem. 2003, 1, 2303.

41. Nizova, G. V.; Kozlov, Y. N.; Shulpin, G. B. Russ. Chem. Bull., Int. Ed. 2004, 53, 2330.

42. Carvalho, N. M. F.; Horn Jr., A.; Antunes, O. A. C.; Appl. Catal., A 2006, 305, 140.

43. Canhota, F. P.; Salomão, G. C.; Carvalho, N. M. F.; Antunes, O. A. C.; Catal. Commun. 2007, 9, 182.

Submitted: April 10, 2010 Published online: December 2, 2010 


\section{Synthesis, Characterization and Catalytic Activity of Two Novel cis-Dioxovanadium(V) Complexes: $\left[\mathrm{VO}_{2}(\mathrm{~L})\right]$ and $\left[\mathrm{VO}_{2}(\mathrm{HLOx})\right]$}

Natália M. L. Silva, ${ }^{a}$ Carlos B. Pinheiro, ${ }^{b}$ Eluzir P. Chacon, ${ }^{a}$ Jackson A. L. C. Resende, ${ }^{a}$ José Walkimar de M. Carneiro, ${ }^{a}$ Tatiana L. Fernández, ${ }^{c}$ Marciela Scarpellini ${ }^{c}$ and Mauricio Lanznaster*,a

${ }^{a}$ Instituto de Química, Universidade Federal Fluminense, Outeiro S. João Batista S/N, 24020-141 Niterói-RJ, Brazil

${ }^{b}$ Departamento de Física, Universidade Federal de Minas Gerais, Av. Antonio Carlos 6627, Pampulha, 31270-901 Belo Horizonte-MG, Brazil

${ }^{c}$ Instituto de Química, Universidade Federal do Rio de Janeiro, Av. Athos da Silveira Ramos 149, Bl. A, 21941-909 Rio de Janeiro-RJ, Brazil

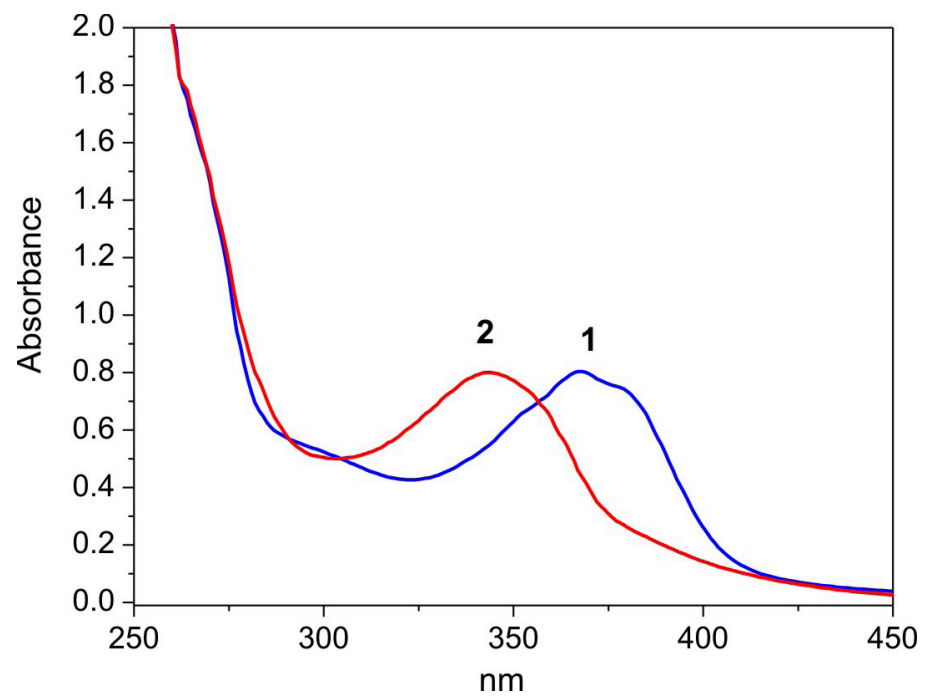

Figure S1. UV-Vis spectra for $\mathbf{1}$ and $\mathbf{2}$ recorded in DMSO solutions. 

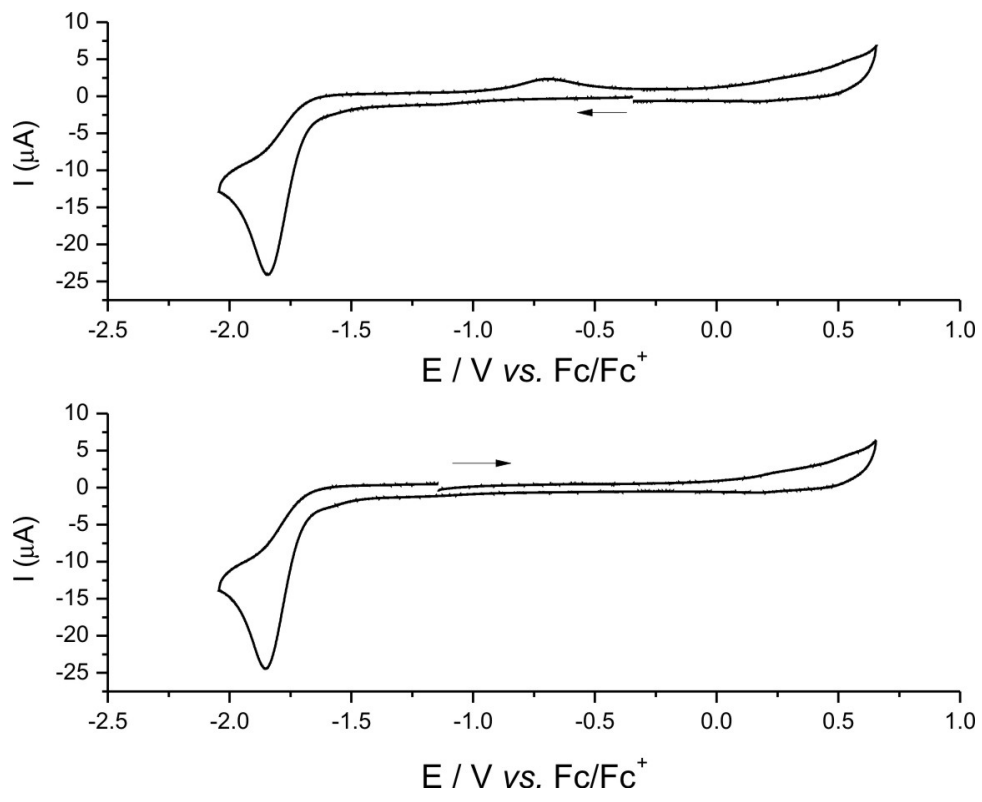

Figure S2. Cyclic voltammograms of complexes 1 in a DMSO/TBAPF $6.1 \mathrm{~mol} \mathrm{~L}^{-1}$ solution, scan rate $=0.1 \mathrm{~V} \mathrm{~s}^{-1}$, working electrode $=$ glassy carbon, reference $=\mathrm{Ag} / \mathrm{AgCl}\left(\mathrm{DMSO} \mathrm{TBAPF}_{6} 0.1 \mathrm{~mol} \mathrm{~L}^{-1}\right)$, auxiliary $=$ platinum wire and ferrocene as internal reference. The arrows indicate the scan directions. This figure illustrates the dependence of the process at $-0.68 \mathrm{~V}$ with the reduction peak at $-1.89 \mathrm{~V}$.
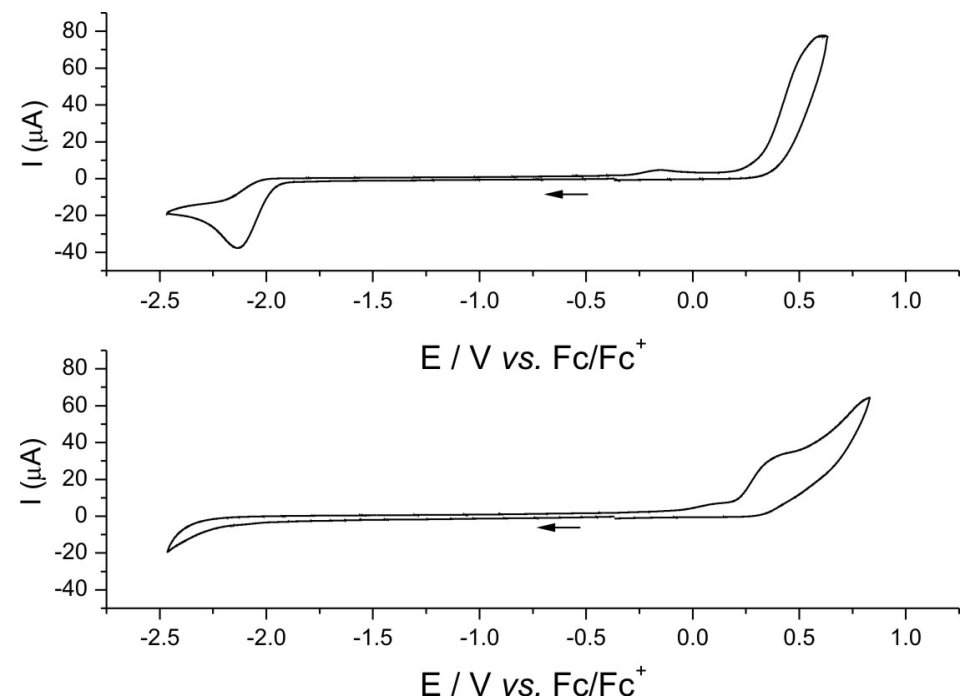

Figure S3. Cyclic voltammograms of the ligands HL (top) and $\mathrm{H}_{2} \mathrm{Lox}$ (bottom) in a DMSO/TBAPF $6.1 \mathrm{~mol} \mathrm{~L}^{-1}$ solution, scan rate $=0.1 \mathrm{~V} \mathrm{~s}{ }^{-1}$, working electrode $=$ glassy carbon, reference $=\mathrm{Ag} / \mathrm{AgCl}\left(\mathrm{DMSO} / \mathrm{TBAPF}_{6} 0.1 \mathrm{~mol} \mathrm{~L}^{-1}\right)$, auxiliary $=$ platinum wire and ferrocene as internal reference. $\mathrm{The}$ arrows indicate the scan direction. 
Table S1. Summary of the crystal structure data collection and refinement for $\mathbf{1}$ and $\mathbf{2}$

\begin{tabular}{|c|c|c|}
\hline Identification code & {$\left[\mathrm{VO}_{2}(\mathrm{~L})\right](\mathbf{1})$} & {$\left[\mathrm{VO}_{2}(\mathrm{Lox})\right](\mathbf{2})$} \\
\hline Empirical formula & $\left(\mathrm{C}_{21} \mathrm{H}_{20} \mathrm{~N}_{3} \mathrm{O}_{4} \mathrm{~V}\right)_{2} \cdot \mathrm{H}_{2} \mathrm{O}$ & $\mathrm{C}_{21} \mathrm{H}_{21} \mathrm{~N}_{4} \mathrm{O}_{4} \mathrm{~V}$ \\
\hline Formula weight & 876.7 & 444.36 \\
\hline Temperature & 293(2) K & 293(2) K \\
\hline Wavelength & $0.71073 \AA$ & $0.71073 \AA$ \\
\hline Crystal system & monoclinic & monoclinic \\
\hline Space group & $\mathrm{P} 21 / \mathrm{c}$ & $\mathrm{P} 21 / \mathrm{c}$ \\
\hline Unit cell dimensions & $\begin{array}{c}a=13.316(3) \AA \\
b=14.293(3) \AA \\
c=22.902(7) \AA \\
\beta=113.70(2)^{\circ}\end{array}$ & $\begin{array}{c}a=10.126(2) \AA \\
b=15.044(3) \AA \\
c=13.143(3) \AA \\
\beta=97.61(3)^{\circ}\end{array}$ \\
\hline Volume & $3991.2(17) \AA^{3}$ & $1984.6(7) \AA^{3}$ \\
\hline $\mathrm{Z}$ & 4 & 4 \\
\hline Density (calculated) & $1.459 \mathrm{mg} \mathrm{m}^{-3}$ & $1.487 \mathrm{mg} \mathrm{m}^{-3}$ \\
\hline Absorption coefficient & $0.533 \mathrm{~mm}^{-1}$ & $0.537 \mathrm{~mm}^{-1}$ \\
\hline $\mathrm{F}(000)$ & 1816 & 920 \\
\hline Crystal size & $0.26 \times 0.25 \times 0.13 \mathrm{~mm}^{3}$ & $0.47 \times 0.22 \times 0.14 \mathrm{~mm}^{3}$ \\
\hline$\theta$ range for data collection & 5.16 to $25.03^{\circ}$ & 3.61 to $26.00^{\circ}$ \\
\hline Index ranges & $\begin{array}{c}-15 \leq h \leq 15,-17 \leq k \leq 17, \\
-27 \leq l \leq 27\end{array}$ & $\begin{array}{c}-12 \leq h \leq 12,-18 \leq k \leq 17 \\
-16 \leq l \leq 16\end{array}$ \\
\hline Reflections collected & 26034 & 23865 \\
\hline Independent reflections & $6986\left[\mathrm{R}_{(\mathrm{int})}=0.0431\right]$ & $3893\left[\mathrm{R}_{\text {(int) }}=0.0351\right]$ \\
\hline Completeness to $\theta=26.37^{\circ}$ & $99.1 \%$ & $99.6 \%$ \\
\hline Absorption correction & empirical & empirical \\
\hline Max. and min. transmission & 0.948 and 0.897 & 0.931 and 0.785 \\
\hline Refinement method & Full-matrix least-squares on $\mathrm{F}^{2}$ & Full-matrix least-squares on $\mathrm{F}^{2}$ \\
\hline Data / restraints / parameters & $6986 / 2 / 540$ & 3893 / 0 / 271 \\
\hline Goodness-of-fit on $\mathrm{F}^{2}$ & 1.169 & 1.088 \\
\hline Final $R$ indices $[I>2 \sigma(\mathrm{I})]$ & $\mathrm{R}_{1}=0.0578, \mathrm{wR}_{2}=0.1291$ & $\mathrm{R}_{1}=0.0379, \mathrm{wR}_{2}=0.0966$ \\
\hline $\mathrm{R}$ indices (all data) & $\mathrm{R}_{1}=0.0872, \mathrm{w}_{2}=0.1386$ & $\mathrm{R}_{1}=0.0502, \mathrm{wR}_{2}=0.1043$ \\
\hline Largest diff. peak and hole & 0.487 and -0.364 e. $\AA^{-3}$ & 0.488 and -0.308 e. $\AA^{-3}$ \\
\hline
\end{tabular}

